\title{
Imprisonment Penalty and Its Inefficacy in Female rehabilitation
}

\author{
Hosein Angouraj Taghavi ${ }^{1, *}$, Nasir Rezaye ${ }^{2}$ \\ ${ }^{1}$ Assistant Professor, Department of Arabic Literature, Chalus Branch, Islamic Azad University, \\ Chalus, Iran \\ ${ }^{2}$ MA of penal law and criminology, Department of Law, Sanandaj Branch, Islamic Azad University, \\ Sanandaj, Iran \\ Email address: Dr.taghavi9@gmail.com
}

Keywords: Imprisonment, Penalty, accused, offence, Society, norm.

\begin{abstract}
Freedom is a human value cherished in any human society. In criminal law, imprisonment as a penalty denies freedom. Custodial penalty is a sort of punishment believed to keep away criminals from human society and helps it move forward. What is the focus of criminological study today and law theorists tend to focus on, is the crimogenesis of this social reaction against criminals. It has undergone a considerable trend in any criminal law including in that of Iran, and answers any offence with imprisonment. The unreasonable increase has resulted countless insoluble problems, and the traditional punishment does not satisfy criminal law theorists, and despite the attempts made to modify it, the results are not promising, because prison has turned into a criminalizing school a part from the considerable expenses resulting from it; prison made resocialization difficult or postponed, rather than rehabilitate the accused. This has turned criminal system into an inefficient one.
\end{abstract}

\section{INTRODUCTION}

\section{The negative consequences of imprisonment "The First Subject"}

Many social theorists and analyst have come to the conclusion that imprisonment, in large, can not be impressive in female acts and ideologies, and as such, imprisonment is not seen as a preventive factor against crime; on the contrary, considering the problems it imposes on the prisoner's family as well as the society, it can fuel many anomalies, and delinquencies including prostitution. The prisoner's humiliation, the normalization of the negative aspects of crime for them, learning more about crime and anomaly in prison, the prisoner's depersonalization, and the like are among what theorists suggest as the consequences of female criminal's imprisonment.

Moreover, they suggest that when a person is imprisoned and deprived of socio-economic activities, many people in the society including the prisoner's family; especially their daughters undergo the effects. The minimum consequence that one's imprisonment can impose their family is that their economic and emotional contact will be cut with the family's sample and this will, in return, have considerably negative consequences. On the other hand, neglecting the role imprisonment and confinement play in the delinquents and criminal's is implied so that society does not need imprisonment. Despite its negative effects on prisoner's society and family, it is, in some cases, seen the only solution. It is however clear that imprisonment and confinement is not an efficient penalty for many criminals, and it can not by itself rehabilitate prisoners, so the jurisdiction is supposed to use other penalties rather than imprisonment if possible, and decrease the socioeconomic and cultural effects related to imprisonment through new methodology of prison-keeping.

Today, considering that imprisonment is suggested as a means of controlling the society and keeping security in Iran, and because it has been little care in the criminal law, it has had considerable negative effects on a prisoner, and their society, each of which are discussed here.

Section1. Criminalization and delinquency in prison:

A Prisoner has a lot of time to use her mind and imagination in prison. If their workforce and imagination is not used in a positive way, i.e. to rehabilitate them, they will be inevitably used in a negative way. The prison-keeping system is sometimes so efficient and well-programmed that a 
prisoner can not act against it, but in some cases, because a prison is low on personnel, it is handled by the prisoners.

Moreover, the possibility of conducting offences and acts like theft, homicide, fight, and battery and self-injure, etc. in prisons have to borne in mind. In addition, as a result of a cumulative life among prisoners, new methodology and techniques in offence are transferred to inexperienced criminals, and imprisonment with a rehabilitative purpose faces many problems and even sometimes leads to a reverse result. That is why exponents of imprisonment suggest: "prison has actually become a crime and criminal-creating environment and it is called the offence institute".

Here the phenomenon- culturalization in prison takes place, which is seen in two forms:

In the first step, for the prisoner herself, i.e. a convict who is imprisoned for a simple offence, may become a professional criminal.

In the second step, for the society, since when freed, the prisoner will diffuse criminal culture and methodology, and a "culturalization through prison" will happen to the society and many people will trend to commit crime because of following the prisoner as a sample (Najafi and Hashem Bigi, 1998).

\section{Theft}

Theft is an offence sometimes happening to prisoners' belongings e.g. food stuff, cash, personal items, and so on, and sometimes happening to the property and documents in a prison, for example, reaching a prison's hospital, a prisoner swipes hygiene things such as medicine and syringe for personal use or selling to other prisoners, or entering the official posts, she may swipe the documents, and instruments.

\section{Section2. Exchange and use of drug}

Another problem in prisons is exchange and use of drug. Today the problem has become a serious problem for prison management. Prisoners inter, disperse and use drug in different ways.

Drug may inter a prison in the following ways:

1. The physical hiding accused and suspects coming back after a leave swallowing or hiding.

2. In personal meeting between prisoners and their families by hiding drug in prisoners' items such as sport shoes, food stuff, cloths, etc.

3. Planned throwing drug into prison's yard at the prisoners' recreation or sport time.

4. Through the officers or personnel's' betray.

5. Receiving and swallowing drug while being transferred between the court, prison, and so on.

6. By trained animals such as birds, cat, etc (Goodarzi, 2003).

The most important crime related to drug, is using it which happens in form of eating (e.g. Opium), and smoking; since smoking drugs leads to problems in prison, the easiest way of using it is injection.

The syringe is also caught in the prison's hospital or enters the prison, although because of lack of enough syringes, several prisoners use the same syringe for injection.

From late 1999 to 2009 fall, $80 \mathrm{Kg}$ of heroin were found in Iranian prisons. During the time, 12 cases were formed to refer to the judiciary. Only $5 \%$ of the cases were related to the police offences.

In addition, another statistic also suggests that among which $23 \mathrm{Kg}$ were heroin and $90 \%$ entered through physical hiding (Goodarzi, 2003).

The Minister of Justice announced about drug criminals:

"Drug criminals must not be imprisoned, because they criminalize other prisoners. Iran has 53 drug prisoners of whom 25-26 thousands belong to addiction and the rest belong to trafficking. They both dirty the prisons and addict other prisoners. According to him, these aspects have to be considered seriously and more innovations have to be provided. 


\section{Dispute}

Dispute is a crime committed in prison. Dispute happens in form of words, abasement, and disorderly conduct, and sometimes in form of physical clashes between prisoner, or prisoners and prison officers. Aggression in prison has several reasons such as the overcrowded of prison while the environment is too limited. The psychological problems in prisons such as loneliness, homelessness, worry for family, etc. are among the reasons fueling aggression in prison.

Therefore, today in prison, it is not only that the aggression and confinements dominating it confines an accused freedom, but also a serious physical punishment damages their physical and psychological integrity, and leads to increasing aggression, and its transfer to others. Meanwhile, weaker prisoners face more serious aggression, but can not help keeping silent in fear of revenge from stronger ones. This has always been going on in prisons and law is being destroyed in this regard.

\section{Self- injury and suicide.}

Prisoners are generally in certain psychological status because of personal problems; they are usually perplexed and mad. The stress as a prisoner sometimes leads to self-injury and suicide. Sometimes, a prison goes on a strike or sews her lips to show her protest.

According to article 170 of prison act 2007, using handcuffs to control and prevent self-injury with the prison president's order is legal, and according to article 172 of prison act, dispute, suicide, and threat to do them are forbidden in prison, and the disobedient will be punished on the disciplinary councils' decision, and the case will be presented to the judiciary officials.

\section{Behavioral deviations and sexual offences in prison.}

Among human's natural needs is sexual instinct that has to be satisfied; prison bans it because of its limits so this instinct is satisfied in prison in forms of lesbianism, etc.

Today, behavioral problems and sexual intercourses in prisons can not be denied. These relationships by themselves are one source of diffusion of dangerous infective and coital diseases such as HIV, and Hepatitis.

The most usual form of sexual anomalies is lesbianism that is the easiest way in prison. In this kind of relationship, the victim is not willing, so it leads to sexual offence, threat, and aggression. Sometimes the need for money, food, and drugs has made the person to accept it. This may start from the first night in prison.

\section{Escape prison.}

Because of the tough conditions in prison, one might want to escape in private cells or in public ones. Sometimes, a prison escapes while being transferred to a hospital, court, etc. under the pretend to changing clothes, or other ways.

\section{Destruction.}

Destructing prison facility is also a common form of crime. It happens in 3 forms:

1. Offensive destruction- happening while protesting a situation, case procedure, suspension;

2. Hidden destruction in which the offenders are not usually discovered;

3. Destruction prison workshop equipments or products.

\section{Threat and blackmail.}

Sometimes prisoners threaten a person through hiding drugs in their belongings and make blackmail. Sometimes they do every thing to gain a sexual purpose.

\section{Keeping and making illegal objects.}

A prisoner uses her imagination to make illegal objects with the tools in prison because of overtime. One such an object is knife or something sharp like it. They do this by rubbing the bed strap against the floor or wall. 


\section{Gamble}

Gamble is a usual crime in prison. This is done with different objects needing no special wares.

\section{Murder.}

A person may homicides; for example in clashes and because of an injury from a knife. Sometimes it is planned and may be because of a problem grown out of prison.

\section{Section 2: Pathogenesis}

Among criticisms on female imprisonment is the unfavorable hygienic condition in prison, and among prisoners. Diseases like HIV, infective diseases are common. There is no exact statistics, but the number of prison patient is much higher than that in community. Study shows it is 5.5-10 times than in community (Eidi, 2002).

Also, the infestation of Hepatitis among prisoners is 9- 10 times and asthma is 4- 17 times as that in ordinary people

Moreover, a researcher suggests that the possibility of developing HIV through addicted prisoners is higher than other crimes (Samiei, 2004).

A president of prisoners suggests: "Basically, the hygienic condition is serious and something to care about; for example, there are wanderers who have not bathed for 2 years and suffer injuries, and we have accommodate them. Prisons are the main source of epidemic diseases and HIV. The increasing number of criminal inmates has led to an increase in HIV patients.

Several factors generally worsen prison hygienic condition"

First- overcrowd and space limitation.

Second- the entering and leaving cycle of inmates.

The last but not the least is the use of the same syringes by several inmates.

In 1999, 2 million hygienic actions were done to take care of inmates in Iran. This decreased the quality of hygienic actions in prisons.

Asthma is a common disease in prison. Study in Evin and Ghasr Prisons in 1997-98 suggested that the percentage of asthma infestation in Ghasr is lower than in Evin. Moreover, the percentage in female inmates is higher than that in the male (Eidi, 2002).

Another hygienic consequence of prison is the psychological hygiene in prison. Psychological hygiene includes every activity that prevents a person from developing psychological disorders.

Prison has a serious effect on inmates that may last for years.

According to Mark Ansel, "Because of its aggression, and limitations, prison is a real physical and psychological punishment. It hurts an inmate's mental integrity, depersonalizes her and creates an unconscious obedience in which the person loses the meaning of freedom, or the other way round; is a rebellious state appearing as aggression.

Today, some Iranian prisons are 250- 400 years old and have to be rebuilt. Moreover, the recent overcrowd has made them more insalubrious. In addition, low education and unsuitable sewage system have led to insect infestation, and caused potential hygienic problems (Mohammadi, 2003).

Some diseases in prison are discussed here:

\section{HIV}

HIV is a disease that invades a person's immune system. It is transferred to a healthy person through the inner liquids of a patient. The transfer through blood may happen via common syringes.

Because most patient are kept in prisons, and rehabilitation centers, much care has to be taken in keeping them and this will increase the number of patients, while statistics show that the maximum cases of HIV develop when using contaminant syringes. 


\section{Hepatitis}

Hepatitis is an infection in the virus flow in which the liver inflates and gradually stops working. This disease has different kinds among which are the Hepatitis viruses A, B, and C. It is transferred through sexual intercourse, milk and blood products. Overcrowding in prison makes the situation ready for its infestation.

\section{Tuberculosis}

Despite developments made, this disease is still a major problem in public hygiene in developing countries. Its infestation is related to malnutrition, low education, and overpopulation.

The most important factor of its infestation in prisons is low culture, malnutrition, etc.

\section{Section 3: Negative behavioral consequences}

Apart from the above, if a person does not die of epidemic and non-epidemic diseases, and neither does she develop a mental disorder, her behavior and attitude will, however, be under influence.

\section{Clause1. Training and diffusing crime in prison}

A criminal adopts a new personality as she enters a prison, and prison makes her more professional rather than changing her positively, because criminals' career will transfer their experience to each other.

A general prison is, in fact, a supreme corruption institute. Destructive plans and experiences are exchanged, so criminals commit higher crimes after being released.

A statistic study suggests that $29 \%$ of people have constantly committed crimes and have been imprisoned. So prison imposes inmates to evil training rather than make a positive change in them.

\section{Clause2. The loss of responsibility, de-socialization, and unemployment}

Another consequence of imprisonment is de-socialization and losing jobs. A criminal who returned to the society after bearing penalties, finds many bans on her employment, and sometimes of government officials' mistrust on her, and long absence from her work place, she will lose her previous property. The more sensitive the jobs to imprisonment, the more difficult it will be to find a job. This will change the freed inmate's attitude not to be absorbed by experienced criminals because these people are sensitive to temptations, so they start offences such as theft, fraud, wandering, and pan-handling.

After being freed, an inmate has no property, nor savings, so she encounters some problems starting a healthy life. Lack of expertise, the requirement of freedom from evil record in offices, mistrust in them, and the high unemployment in Iran returns them to the prison.

On the other hand, prison socially isolates the inmate. A considerable number of families, relatives, friends, and neighbors deny her and are not willing to contact with her and this will get her to join criminal bands.

Another consequence of imprisonment is that a prisoner feels that she gets free facility, and the government has to provide her the minimum facility she needs. This will lead to her reluctance and she will feel irresponsible.

\section{Clause3. Prisoner's humiliation}

Even in its lowest level, punishment is destructive and against people's self-respect. Strong focus on punishment has no positive result for an inmate. That is why many authors use Islamic thoughts to discourage society from punishing criminals.

According to Limert- the British criminologist- a criminal can use her deviated behavior to defense herself and finally accept a deviated social status (Najafi and Hashem Bigi, 1998).

In long-term imprisonment, the possibility of family destruction is too high and the person is deprived of a respectful life. 


\section{Clause4. Negative psychological effects}

Everyone certainly enjoys being free, because they can do whatever they like. So the consequence of freedom is the power to choose, but while being in prison, an inmate undergoes such limitations as separation from family and society leading to worries about family, and the fear that friends and relatives may realize that one is being imprisoned, anxiety about the future job, to name a few. These perplexities because o penalty and the special look at the dim future will lead in anomalies in a prisoner, so of rehabilitating is replaced by the following negative consequences:

\section{Depression and anxiety;}

Depression is one of the commonest consequences of any undesirable event. It is known by psychologists as a form of a normal fear developed from any danger. The first symptom of depression is anxiety. Several factors such as the hereditary, social,... ones result in anxiety and depression. Loneliness and de-socialization are among the most important social factors (Mitchel, 1980).

According to Samb and Difberger, $10-15 \%$ of people in custody and prison suffered sever psychological illnesses, half of which may relate to self-destructive behaviors, and 10 percent may show such dangerous behaviors as suicide (Mohseni, 2003).

Psychological disorders may result in loneliness, self-denial, self-destruction, and suicide so that some psychologists suggest that suicide is the most common reaction of depression.

\section{Self-destruction}

As mentioned above, one of the disorder people undergo is hurting or injuring oneself; the person does not always commit suicide, but shows a less sever reaction as self-denial, life of a recluse, and self-destruction.

Self-destruction happens among prisoners because of the following reasons:

- It might be an attempt to commit suicide.

- To gain the control of an environment.

- As a reaction to tension and anxiety. This kind is more common among female inmates rather than male.

\section{Suicide}

The most sever and dangerous kind of psychological disorders is suicide. It results from two things: because of predominant disorders, or under pressures from the environment. Among environments causing it is prison. "A person, in fact, has to adopt herself to an environment where there is a jungle-like condition".

When a prisoner can not adopt such a feeling, there is a contradiction between their personality and prison environment. Most studies show that most suicides are committed in the first days of imprisonment, and any conviction has been decided on (Durkim, 1999).

Such a decision about specially relating to new criminals or those with lower crimes probably leads to suicide, so professional criminals seldom commit suicide.

\section{Section4. The negative effect of prison on society}

Apart from the above, prison results in countless consequences and problems in society.

Economic consequences are the first consequence imposed to a person's life and society. Huge amount of money is spent to hire disciplinary, officials, educational, health-care, rehabilitative, and assistance personnel, and prison-keeping expenses, prisoner-keeping, hospital equipment and construction, etc. Those are unnecessary expenses for society.

There are 150-160 prisoners in Iran for each of whom the real daily expense is about 7000 Rials, i.e. a large expense per year; that is only the expenses of long-term imprisonments while each year, some 700-800 imprisonments are issued for which the convicts do not afford to pay; those convicts are freed after a while whole expense is too much for the society. 
A survey of 969 financial convicts suggested that 50 of them financially supported 500 workers and 549 of them supported 50; once those people were imprisoned, their workers lost their jobs.

According to the Minister of Justice, "such convictions as imprisonment which impose society considerable expenses and lead to considerable corruptions are against human rights".

Another major problem is the limited space of prisons in Iran; the consequence of which is the impossibility of conducting educational, medical, rehabilitative and other programs.

Statistics suggest that each 54 seconds, one person is imprisoned; this is while the prison can not afford to pay for them; for example, only Ghasr prison has the capacity of 1800 inmates, while there are 9600 in it.

According to the state prison chief, "while the capacity of each prison is $50-60$ people, almost 160.000 are kept in them; now we have 100.000 extra inmates.

\section{CONCLUSION AND RECOMMENDATIONS}

As mentioned above, imprisonment as a traditional way of penalizing is not suitable for today's society; it imposes society considerable expenses while desirable results are not obtained. In addition, it is a potential place for various corruptions, so it has been given the thought of being replaced with any better options. To sum up, replacing imprisonment can serve two major purposes:

1. Find an alternative with less severely negative consequences.

2. Decrease the number of prison convicts from dangerous criminals.

The author recommends a profound study of the subject matter with the hope to find a better penalty system to help human rights to improve.

\section{References}

[1] Durkim, E. (1999). Suicid, translated by Nader Salarzadeh Amiri.

[2] Eidi , A. (2002). Aforementioned.The report of the us secretary of Justice on in gestation of IHV in prison, 2002, "Rehabilitation and correction", 1(5): 37-50.

[3] Goodarzi, M. R. (2003). Prison deprivations, the specialized magazine of Olum-e- Razavi University, 9(3): 17-118.

[4] Mitchel, R. (1980). Deoression, translated by Gholamreza Khajehpour, Mina publication.

[5] Mohammadi, D. (2003). Imprisonment and replacements, Rehabilitation and correction magazine, 2(16): 39-52.

[6] Mohseni, R. (2003). The cultural- law magazine of prosecution.

[7] Najafi, A., \& Hashem Bigi, H. (1998). Criminology license. Tehran: Shahid Beheshti, Publication.

[8] Samiei, A. (2004). How to decrease prison's population, Simorgh monthy, 1(2): $61-73$. 